напороть ногу на сук и напороть ерунды; заваривать чай и заваривать кутерьму / кашу; отсутствуют глаголы говорения нести, молоть).

Таким образом, при исследовании омонимии, которая традиционно рассматривается как сложившийся итог языкового развития, важно учитывать, во-первых, языковую информацию, которая выходит за временны́е рамки синхронного состояния языка, и, во-вторых, массив экстралингвальных данных, относящихся к среде, в которой происходило развитие языка. Такой интенсивный подход дает возможность углубиться в отдельное явление и рассмотреть его с разных сторон, что часто приводит к нестандартным результатам.

Ахманова О. С. Словарь омонимов русского языка. М., 1974.

Жуйкова М. Роль внутрішньої форми ідіоми та ії образної основи в мовнокультурній реконструкції // Учен. зап. Таврического нац. ун-та им. В. И. Вернадского. 2009. Т. 22 (61). № 4 (2). Филология. С. 101-108.

Жуйкова М. Асистемна семантична деривація: походження оцінного предиката вигоріти // Східнослов'янські мови в їх історичному розвитку : зб. наук. праць, присвяч. 70-річчю від дня народження проф. П. І. Білоусенка / відп. ред. Р. О. Христіанінова. Запоріжжя, 2018. С. 44-53.

DOI $10.31168 / 7996-2700-3.47$

\author{
E. В. Захарова \\ Институт языка, литературы и истории КарНЦ РАН \\ Петрозаводск, Россия \\ katja.zaharova@mail.ru
}

\title{
Типы традиционных людиковских поселений по данным ойконимии*
}

Особенностью ойконимической системы Карелии, в которую входят и названия поселений карелов-людиков, является функционирование в двух разноязычных форматах: на официальном уровне на русском языке, неофициально - на одном из прибалтийско-финских языков

\footnotetext{
* Публикация подготовлена в рамках выполнения проекта РФФИ № 19-012-00068А «Ойконимическая система южной Карелии: на стыке традиций и инноваций».

(C) Захарова Е. В., 2019 
(карельском или вепсском): например, pyc. Порожек / люд. Koskenkylä, рус. Половина / люд. Pošte.

Анализ наименований традиционных сельских поселений людиковского ареала позволил выявить набор основных номинативных моделей, свойственных разным поселенческим типам.

1. О тан т ропони мны е наз ван и я. В этой группе выделяется несколько пластов: ойконимы, в основе которых фиксируются нехристианские прибалтийско-финские имена (д. Прякки $\sim$ Прякку / Präkkä Präkke Präkänkylä - cp. приб.-фин. Präkkä, некалендарное имя); названия, образованные от карельских вариантов христианских имен (д. Декнаволок / D'eku(n')niem(i) - cp. карел. D'ekki, D'ekku, Jekki, Jekku < pус. Eфим, Ефимий [Nissilä, 1967, 24-25]); названия, в официальной и народной формах которых выступает календарное имя - соответственно в русском и прибалтийско-финском вариантах: д. Андреев Наволок / Ondrein'n 'iеm.

Ойконимы такого типа маркируют основную разновидность северных деревень - однодворное / малодворное поселение, в названии которого закрепилось имя или прозвище первопоселенца. Как правило, они фиксируются в составе гнезд или кустов поселений.

2. Названия, в основе которых содержатся те р м и ны с с е м ан т и к й 'п о с е л е н и е', выступающие как самостоятельно, так и в роли детерминантов сложных ойконимов. В них выделяются термины прибалтийско-финского происхождения kylä, hier(u) 'деревня', kond $(u)$ 'земельный участок; однодворная деревня с участком земли' [LMS, 150]: д. Средняя Пряжа / Kes'kylä, д. Сургуба / Suurlaht Suurlahtenkylä; д. Владимирская / Kond $\sim$ Kondunkylä, д. Кондопога / Kompohd '(*Kondpohd'). Используются также адаптированные в карельской языковой среде русские термины d'eren' ‘деревня', s'ola 'село': д. Васильевская / S'ola $\sim$ S'oland'eren' $~ S$ 'olankylä $\sim$ S'olanhieru; hutor 'хутор': д. Курганов Хутор / Hutor.

На различные в социально-экономическом плане типы поселений указывают и следующие термины: погост 'деревня, где находилась церковь с кладбищем’ [СРГК, 4, 613] (д. Погостская Мунозерский nогост / Mun'd'ärvem pagast); слобода 'крестьянское поселение, созданное землевладельцем на льготных условиях на пустующей земле' [Воронин, 1935, 40] (д. Слобода / Sloboda); yсадище 'господский дом на селе со всеми ухожами, садом, огородом и пр.' [Даль, 4, 524] (д. Усадище / 
Usadišš); nycmomb 'невозделанная или заброшенная земля; пустошь' [СРГК, 5, 356], в ойконимии обычно 'поселение на месте запустевшей деревни' [Муллонен, 2018] (д. Пустоша / Pustoš); новинка 'пашня, очищенная от леса' [СРГК, 4, 29] (д. Еркоева Новинка).

Кроме того, в ойконимической системе карелов-людиков в разряд ойконимных показателей перешли в ряде случаев детерминанты -mägi, -šelg 'возвышенность, холм, гор(к)а', выступающие в ойконимах сложной структуры, например д. Курганова Сельга / Kurhananšelg. Будучи последовательно и многократно представленными в названиях отдельных поселений, особенно образующих поселенческое гнездо, они переосмыслились из ландшафтных терминов в ойконимные.

3. Оттопонимны е, или в торичны е, ойконимы. Это названия, образованные от наименований природных объектов, при которых возникли поселения. Данная номинативная модель продуктивна в приложении к кустам / гнездам поселений, одиночным деревням, хуторам и выселкам: д. Шуя / Šuoju $\sim \breve{S} u o j u n k y l \ddot{a} \sim \breve{S} u o j u n p o g o s t a$; д. Святнаволок / Pyhän 'iem Pyhän'iemenkylä.

4. Названия, содержащие указание на ра с п л о же н и е м а о дворной деревни внутри куста / гнезда поселе н и й. К этому типу относятся наименования, в составе которых фиксируются термины $a g d$ ' 'конец' (д. Южный Конец / Suviagd'); с̌ирри 'угол' (д. Шуйская Чуna / Šuojun С̌uppu); kesk 'середина, средний' (д. Средняя Пряжа / Kes'kylä). К этой же группе относятся ойконимы, в которых содержится указание на сторону света или относительное местоположение: suvi 'лето, юг' (д. Пялозеро Южное / Suvikylä); pohd' 'север' (д. Северный Конеи, Pohd'ain 'e kylä Pohd'agd'); liide 'восток' (д. Восточная / Liidekylä); luodeh 'запад’ (д. Западная / Luodehkylä); ylä 'верхний' (д. Кузьминская / Ylägjä); ala 'нижний' (д. Нижние Bидань / Alaižagja).

Анализ ойконимического материала показывает, что разные типы поселений характеризуются определенным набором разновременных номинативных моделей. Ареально-типологическая методика исследования в приложении к ойконимическому материалу позволит в дальнейшем реконструировать схему освоения исследуемой территории и этапы формирования традиционных поселений гнездового типа. 
Воронин Н. Н. К истории сельских поселений феодальной Руси: погост, слобода, село, деревня. Л., 1935.

Даль В. И. Толковый словарь живого великорусского языка : в 4 т. 2-е изд. СПб. ; М., 1880-1882.

Муллонен И. И. Материалы к «Словарю топонимов Карелии» // Альманах североевропейских и балтийских исследований. 2018. Вып. 3. URL: http://nbsr. petrsu.ru/journal/article.php?id=1049.

СРГК - Словарь русских говоров Карелии и сопредельных областей : в 6 вып. / под ред. А. С. Герда. СПб., 1994-2005.

LMS — Lyydiläismurteiden sanakirja / toim. J. Kujola. Helsinki, 1944.

Nissilä V. Die Dorfnamen des alten ludischen Gebiets. Helsinki, 1967.

DOI 10.31168/7996-2700-3.48

\section{Ю. В. Зверева}

Пермский государственный гуманитарно-педагогический университет Пермь, Россия zv.ul@mail.ru

\section{Микротопонимы пермского происхождения на территории Красновишерского и Юрлинского районов Пермского края*}

В работе рассматриваются микротопонимы Верх-Язьвинского сельского поселения Красновишерского района и Усть-Зулинского поселения Юрлинского района Пермского края.

Территория Верх-Язьвинского поселения интересна тем, что является местом компактного проживания коми-язьвинцев - одного из коренных народов Пермского края. Большинство финно-угроведов считает коми-язьвинский язык диалектом коми-пермяцкого языка [см.: Лыткин, 1961; Баталова, 2002; и др.]. Изучение быта и культуры коми-язьвинцев началось еще в XIX в., в XX-XXI вв. оно продолжилось. В трудах современных исследователей рассматриваются этнографические особенности народа [Чагин, 2012; Голева, 2014] и его

\footnotetext{
* Исследование выполнено при финансовой поддержке РФФИ в рамках научного проекта № 18-012-00555 «Мир и человек в зеркале имен собственных (на материале ономастики Пермского края)».

(C) Зверева Ю. В., 2019
} 